\title{
EVALUATION OF THE WEAR BEHAVIOR OF NITRIDE-BASED PVD COATINGS USING DIFFERENT MULTI-CRITERIA DECISION-MAKING METHODS
}

\author{
OCENA OBRABE NITRIDNEGA PVD NANOSA Z UPORABO \\ RAZLIČNIH METOD VEČKRITERIJSKIH POSTOPKOV \\ ODLOČANJA
}

\author{
Yılmaz Küçük $^{1}$, Ahmet Öztel ${ }^{2}$, Mehmet Yavuz Balalı ${ }^{3}$, Mecit Öge ${ }^{1}$, \\ Mustafa Sabri Gök ${ }^{1}$ \\ ${ }^{1}$ Bartin University, Faculty of Engineering, Department of Mechanical Engineering, 74100 Bartin, Turkey \\ ${ }^{2}$ Bartın University, Faculty of Economics and Administrative Sciences, Department of Management, 74100 Bartın, Turkey \\ ${ }^{3}$ Turkish Military Academy, 06654 Ankara,Turkey \\ mecitoge@bartin.edu.tr, mecitoge@yahoo.com
}

Prejem rokopisa - received: 2016-03-02; sprejem za objavo - accepted for publication: 2016-05-05

doi:10.17222/mit.2016.041

\begin{abstract}
In this study, AISI 7131 (16MnCr5) case-hardened steel specimens were prepared in two groups, carbonitrided and without heat treatment, and the specimen surfaces were coated with three different coating materials (CrN, TiAlN and TiN) as a single layer using the physical vapor deposition (PVD) cathodic arc method. The wear behaviors of the coated specimens were tested with the micro-abrasion method. The test results of the micro-abrasion wear tests were analyzed with Multi-Criteria Decision Making (MCDM) techniques to determine the combination of coating and heat treatment that yields the lowest wear rate. According to the analyses conducted with the Technique for Order Preference by Similarity to Ideal Solution (TOPSIS), Multiple Attribute Utility Theory (MAUT) and Compromise Programming (CP) MDCM techniques, the TiAlN coating exhibited the best wear performance. The MAUT and CP methods produced an identical ranking of the alternatives, whereas a slight deviation was found in the ranking with the TOPSIS method. Uncoated and CrN-coated specimens exhibited the worst wear performance of all the MCDM methods.

Keywords: wear, micro-abrasion, multi-criteria decision making, PVD coating

V študiji sta bili pripravljeni dve skupini jekla za cementacijo AISI 7131 (16MnCr5), karbonitrirana jekla in jekla brez toplotne obdelave, katerih površina vzorcev je bila prekrita s tremi različnimi nanosi (CrN, TiAlN in TiN) v enem sloju, s pomočjo fizikalne depozicije preko plinske faze (angl. PVD) z metodo obloka. Obnašanje vzorcev z nanosom pri obrabi je bilo preizkušeno z mikroabrazijsko metodo. Rezultati preizkusov mikroabrazijske obrabe so bili analizirani z uporabo večkriterijske tehnike odločanja (angl. MCDM), za določitev kombinacije nanos - toplotna obdelava, ki kaže najmanjšo hitrost obrabe. Glede na analize, ki so bile izvedene s pomočjo tehnike, ki je najbližja idealni rešitvi (angl. TOPSIS), s teorijo večkratne prednosti (angl. MAUT) in s programsko tehniko (angl. CP) MDCM-kompromisov, je najboljšo odpornost na obrabo pokazal TiAlN MAUT- in CP-metodi dajeta enakovredne alternative, medtem ko je bilo manjše odstopanje ugotovljeno pri TOPSIS-metodi. Vzorci brez nanosa in s CrN nanosom so pokazali najslabšo odpornost na obrabo od vseh MCDM-metod.

Ključne besede: obraba, mikroabrazija, večkriterijsko odločanje, PVD-nanos
\end{abstract}

\section{INTRODUCTION}

Many of the machine parts used in automotive, aircraft and machine tools are exposed to mechanical loads under certain conditions in which they are in contact with their counterparts. Hence, many researches are conducted to understand the tribological properties of such parts to improve their service life and reduce the maintenance costs. One of the methods used to solve this problem is the thin-film coating application. In the thinfilm coating process, the adhesive characteristics and hardness of the coatings are improved through optimization of the coating parameters using various deposition techniques.

In this work, the coatings ( TiN, $\mathrm{CrN}$ and TiAlN) widely employed in actual industrial applications were selected and deposited by the cathodic arc-evaporation
PVD technique in order to make a comparative analysis of their tribological performances. In general, TiN and $\mathrm{CrN}$ coatings are known to be the most commonly employed thin hard coatings, ${ }^{1,2}$ whereas TiAlN is generally used for the coating of cutting tools in special machining operations. ${ }^{3}$

TiN, CrN and TiAlN thin hard coatings exhibit different wear behaviors due to their differing characteristic properties, such as friction coefficient, hardness, abrasive wear and corrosion resistance under various service conditions. ${ }^{3,4}$ Abrasive wear is one of the most commonly known wear mechanisms and it is of great importance in terms of the evaluation of the wear performance of coatings and the selection of abrasive wear-resistant coatings suitable for specific applications. ${ }^{5}$

The micro-abrasion wear-testing method is widely used to determine the abrasive wear resistance of thin 
hard coatings. ${ }^{6-11}$ In the micro-abrasion wear test, the most effective test parameters that affect the test results can be classified as the rotational speed of the ball, ${ }^{12,13}$ the normal load, ${ }^{12}$ the ball sliding distance, ${ }^{13-14}$ the ball surface condition ${ }^{15}$, the size $\mathrm{s}^{6,16-19}$ and the type of abrasive particle in the slurry. ${ }^{20}$

The coating materials may exhibit different wear performances depending on various test conditions. Therefore, it is necessary to determine the optimum test parameters that simulate the best service conditions. To select the most suitable material for a specific application, the criteria affecting the material selection should be properly identified. ${ }^{21,22}$ The selection of suitable thin hard coatings having the best wear performance among several choices for a specific application can be considered as a MCDM problem. ${ }^{23-24}$ The selection of the best method for a given problem is yet another important issue with no definite answer. ${ }^{25} \mathrm{~A}$. Abrishamchi et al. ${ }^{26}$ state that the selection of an appropriate MCDM from a long list of available MCDM methods is a multi-criteria problem itself. There is no single MCDM technique that can be deemed superior for all decision-making problems. ${ }^{27}$ TOPSIS, EXPROM2 (Preference Ranking Organization Method for Enrichment Evaluation), VIKOR (Višekriterijumsko Kompromisno Rangiranje - Multicriteria Optimization and Compromise Solution), ELECTRE (Elimination and Choice Expressing the Reality), Linear Assignment Method, and COPRAS (Complex Proportional Assessment) ${ }^{24}$ are among the MCDM methods used by researchers for optimum selection among a variety of options in industrial problems.

A determination of the effects of the coating material and the nitriding processes on the wear behaviour of coating is a complex, multi-factorial problem and a limited number of studies are available in the literature on the use of MCDM techniques in the selection of coating materials. The TOPSIS method was used by A. Chauhan and R. Vaish ${ }^{27}$ for the selection of the best alternative among hard coatings based on their hardness, Young's modulus, thermal expansion coefficient, $H / E$ and $H^{3} / E^{2}$ ratios. H. Çalışkan et al. ${ }^{24}$ used EXPROM2, TOPSIS and VIKOR methods to select the best coating material among a variety of multicomponent nanostructured boron-based hard coatings deposited using magnetron-sputtering and ion-implementation-assisted magnetron-sputtering methods in consideration of their hardness, Young's modulus, elastic recovery, friction coefficient, and critical load. Again, the EXPROM II, TOPSIS and VIKOR methods were used by H. Çalışkan et al. ${ }^{24}$ to determine the best selection among a variety of materials for tool holders used in hard milling.

TOPSIS was developed by Hwang and Yoon (1981) ${ }^{28}$ as a value-based compensatory method in conception and application, ${ }^{29}$ which attempts to choose alternatives that are both closest to the positive-ideal solution and farthest from the negative-ideal solution. ${ }^{30}$ The benefit criteria are maximized and the cost criteria are mini- mized by a positive-ideal solution, and the opposite applies for the negative-ideal solution. ${ }^{31}$ TOPSIS provides a cardinal ranking of alternatives through the full use of the attribute information without a requirement for independent attribute preferences. ${ }^{32,33}$ The main strengths of the TOPSIS method can be listed as its understandable principle and easy implementation, its applicability, which requires a collection of precise and overall information, ${ }^{34}$ a consideration of both positive and negative ideal solutions, the provision of a well-structured analytical framework for ranking of alternatives, and the use of fuzzy number to deal with alternatives. ${ }^{35}$ The requirement of vector normalization for multidimensional problems can be regarded as a weakness of the method.

MAUT is a systematic method for the analysis and identification of multiple variables for obtaining a decision on a common basis. ${ }^{36}$ In this method, a multi-attribute utility function is derived, which requires single utility functions and related weighting factors. ${ }^{37,38}$ For an evaluation of the performance criteria individually in the same units, single utility functions are used as a means to render their aggregation possible in the multiattribute utility function. In this procedure an objective is set and attributes are established for the goal; a range of attributes are set; single utility functions are derived for each attribute; weighting factors are estimated for each attribute; and a multi-attribute utility function is derived. ${ }^{39}$

The MAUT strategy allows the decision maker to make more objective decisions based on their experience and the result of the analysis.

The CP method was first developed by M. Zeleny ${ }^{40}$ and later extended by A. Bárdossy, I. Bogárdi, L. Duckstein $^{41}$ as composite programming for dealing with problems of a hierarchical nature. $\mathrm{CP}$ is within the class of distance-based, multi-criteria analytical methods, designed to identify non-dominated solutions, closest to an ideal solution by some distance measure. ${ }^{42}$ Its simple structure is one of the main advantages of this method. This is a simple and easily understandable method that provides good performance when compared with complicated and time-consuming methods. ${ }^{43}$

In this study the micro-abrasion wear behaviour of single-layer $\mathrm{CrN}$, TiN and TiAlN coatings was investigated using the fixed-ball micro-scale abrasion test. Afterwards, some of MCDM techniques such as TOPSIS, MAUT and CP, were implemented to compare their outputs as a means to determine the thin hard coating having the highest wear resistance. As indicated, there are studies ${ }^{23-24,28}$ available in the literature on the use of the TOPSIS method for the selection of the best alternative among a variety of coating applications. In this study the MAUT and CP methods are used to make a comparative analysis between TOPSIS and these methods. Also, among the other MCDM methods, the TOPSIS, MAUT and CP methods were chosen for their widespread usage, ${ }^{44}$ easy computation and for being 
within the same class of unique synthesis criterion approaches in which different points of view are merged into a unique functional structure for further optimization, which in turn facilitates the solution of material selection problems. ${ }^{45}$

\section{MATERIALS AND METHODS}

\subsection{Substrate and coating}

Test samples made of AISI 7131 (16MnCr5) steel with a diameter of $40 \mathrm{~mm}$ and a thickness of $10 \mathrm{~mm}$ were used as a substrate for the deposition of TiN, TiAlN and $\mathrm{CrN}$ thin hard coatings. After the sample polishing process, all the test samples were subjected to a carburizing process performed in accordance with the heat treatment procedure given in Figure 1.

The substrate surface is hardened through a duplex surface treatment, a combination of nitriding and carburizing, since most of the applied forces must be supported by the substrate due to the thin structure of the PVD coatings. ${ }^{46-48}$ The nitriding process can provide a significantly high wear and adhesion resistance for TiAlN coatings. ${ }^{49}$

Therefore, in this study, in addition to carburizing, a nitriding process was also applied to some samples to determine its synergistic effect on the abrasive wear behaviour of thin hard coatings. The nitriding process parameters are given in Table 1. The list of prepared samples is given in Table 2. After the carburizing and/or nitriding surface-hardening processes, polishing was performed as the last operation before the deposition process to remove the white layer (oxide or nitride layer) emerging during the heat treatment and having an adverse effect on the coating's adhesion. ${ }^{50}$ The average surface roughness of the polished samples was measured as $R_{\mathrm{a}}=0.02 \mu \mathrm{m}$ after measurements conducted with a Mitutoyo SJ 201 profilometer. Before the coating process, the sample surfaces were washed 2 times with an alkaline detergent using an ultrasonic washing device. Then, the samples were washed 3 times with distilled

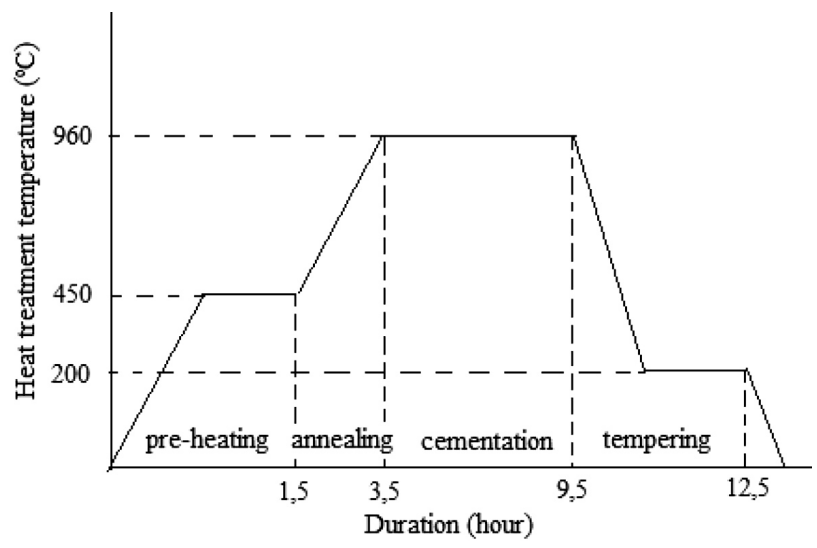

Figure 1: Process diagram of carburizing

Slika 1: Diagram poteka naogljičenja water, each time for a period of $30 \mathrm{~s}$, and then dried with hot air.

Table 1: Nitriding parameters

Tabela 1: Parametri nitriranja

\begin{tabular}{|c|c|}
\hline Process type & Plasma nitriding \\
\hline Temperature & $480{ }^{\circ} \mathrm{C}$ \\
\hline Duration & $10 \mathrm{~h}$ \\
\hline Gas mixture/ratio & Nitrogen-Hydrogen / 3:1 \\
\hline Pressure & 2.5 mbar (in vacuum) \\
\hline
\end{tabular}

Table 2: Test sample classification

Tabela 2: Razvrstitev preizkusnih vzorcev

\begin{tabular}{|c|c|c|c|}
\hline $\begin{array}{c}\text { Coating } \\
\text { material }\end{array}$ & Carburizing & Nitriding & Notation \\
\hline $\mathrm{CrN}$ & + & - & $\mathrm{CrN}$ \\
\hline $\mathrm{CrN}$ & + & + & $\mathrm{CrN}+\mathrm{N}$ \\
\hline $\mathrm{TiN}$ & + & - & $\mathrm{TiN}$ \\
\hline $\mathrm{TiN}$ & + & + & $\mathrm{TiN}+\mathrm{N}$ \\
\hline $\mathrm{TiAlN}$ & + & - & $\mathrm{TiAlN}$ \\
\hline $\mathrm{TiAlN}$ & + & + & $\mathrm{TiAlN}+\mathrm{N}$ \\
\hline
\end{tabular}

Table 3: PVD deposition parameters

Tabela 3: Parametri PVD-depozicije

\begin{tabular}{|c|c|c|c|}
\hline Parameter & \multicolumn{3}{|c|}{ Coating material } \\
\hline & TiN & CrN & TiAlN \\
\hline Cathode current & $70 \mathrm{~A}$ & $70 \mathrm{~A}$ & $60 \mathrm{~A}$ \\
\hline Bias voltage (DC) & $50-60 \mathrm{~V}$ & $50-60 \mathrm{~V}$ & $50-60 \mathrm{~V}$ \\
\hline Number of cathode & 6 & 6 & 8 \\
\hline Duration & $1 \mathrm{~h}$ & $1 \mathrm{~h} 30 \mathrm{~min}$ & $1 \mathrm{~h} 10 \mathrm{~min}$ \\
\hline
\end{tabular}

Following the ion bombardment on the coated sample surface, thin hard coatings were deposited on the sample surfaces using the parameters given in Table 3 by the cathodic arc PVD technique.

\subsection{Micro-abrasion test}

The micro-abrasion wear test is a widely used method in the determination of the abrasive wear performance of thin hard coatings. In this study, micro-abrasion wear tests were carried out using a fixed-ball-cratering device shown in Figure 2. In micro-abrasion tests, an

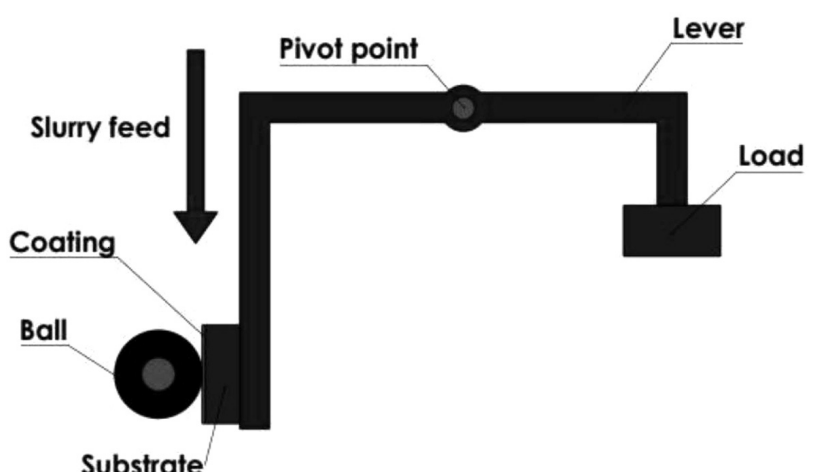

Figure 2: Scheme of the fixed-ball micro-abrasion test set up Slika 2: Shema postavitve mikro-abrazijskega preizkusa s fiksno kroglo 


\section{MATERIALI IN TEHNOLOGIJE/MATERIALS AND TECHNOLOGY (1967-2017) - 50 LET/50 YEARS}

\section{Y. KÜÇÜK et al.: EVALUATION OF THE WEAR BEHAVIOR OF NITRIDE-BASED PVD COATINGS USING DIFFERENT ...}

abrasive slurry composed of $25 \mathrm{~g}$ of $\mathrm{SiC}$ in $75 \mathrm{~mL}$ distilled water for each abrasive mesh size $(800,1000$ and 1200) mesh, was applied as 3 drops per minute, onto an AISI 52100 steel polished ball with a diameter of 25.4 $\mathrm{mm}$.

\subsection{Multi-criteria decision making method}

\subsubsection{Definition of the problem and setting up}

Coating materials may yield differing wear results under different test conditions. In such situations a determination of the best choice for a coating material may be addressed as a multi-criteria decision making (MCDM) problem. ${ }^{23,24}$ In this study, implementation of MCDM methods is based on the assumption that each wear value obtained under different conditions is a criterion. The alternatives for the coating material are shown in Table 4.

Table 4: Alternatives for coating material Tabela 4: Izbire materiala za nanašanje

\begin{tabular}{|c|c|}
\hline Alternative & Material \\
\hline A1 & CrN \\
\hline A2 & N+CrN \\
\hline A3 & N+TiAlN \\
\hline A4 & N+TiN \\
\hline A5 & TiAlN \\
\hline A6 & TiN \\
\hline A7 & Uncoated \\
\hline
\end{tabular}

Table 5: Wear test factors

Tabela 5: Faktorji preizkusa obrabe

\begin{tabular}{|c|c|c|}
\hline Abrasive (mesh) & Load $(\mathrm{N})$ & Speed $(\mathrm{r} / \mathrm{min})$ \\
\hline 800 & 0,5 & 45 \\
\hline 1000 & 1 & 90 \\
\hline 1200 & 1,5 & 140 \\
\hline
\end{tabular}

The factors for the wear test and their levels are shown in Table 5. 27 tests were conducted with these coating materials for three different factors. On the assumption that the wear rate found in each test is a criterion for a decision, our criteria can be organized as C(Abrasive, Load, Speed). Our criteria and the test parameters are shown in Table 6.

\subsubsection{Entropy method for criteria weighting}

In MCDM problems, the significance level of each criteria cannot be the same. A weighting value must be specified for each criterion to evaluate this significance level. Several objective weighting methods are proposed by researchers. One of the most prominent of them is the entropy method. This method is based on the concept of Entropy, which is defined as a measure of uncertainty by Shannon. ${ }^{51}$ In the information theory, entropy is a criterion for the level of uncertainty given by discrete probability distribution, such that, the ones with significantly high values exhibit higher levels of uncertainty. ${ }^{52}$ If the decision matrix with sufficient information for the alternatives is available, then the entropy method can be used as a tool to determine the significance rankings, i.e., the weighting values of the criteria. ${ }^{28,53-55}$ The method can be summarized as follows: ${ }^{56-57}$

Let the decision matrix for a multi-criteria decision making problem with $m$ alternatives and $n$ criteria be Equation (1):

$$
\begin{aligned}
& \begin{array}{llllll}
X_{1} & X_{2} & \ldots & X_{j} & \ldots & X_{n}
\end{array} \\
& \left.D=\begin{array}{c}
A_{1} \\
A_{2} \\
\vdots \\
A_{i} \\
\vdots \\
A_{m}
\end{array} \mid \begin{array}{cccccc}
x_{11} & x_{12} & \ldots & x_{1 j} & \ldots & x_{1 n} \\
x_{21} & x_{21} & \ldots & x_{2 j} & \ldots & x_{2 n} \\
\vdots & \vdots & \vdots & \vdots & \vdots & \vdots \\
x_{i 1} & x_{i 2} & \ldots & x_{i j} & \ldots & x_{i n} \\
\vdots & \vdots & \vdots & \vdots & \vdots & \vdots \\
x_{m 1} & x_{m 2} & \ldots & x_{m j} & \ldots & x_{m n}
\end{array}\right]
\end{aligned}
$$

Here, $x_{i j}$ : is the success value of $i$-th alternative according to $j$-th criterion. $i=1,2, \ldots, m$ and $j=1,2, \ldots, n$.

Here, $A$ and $X$ stand for the alternative and the criterion, respectively.

Step 1:

With the following Equation (2):

$$
r_{i j}=\frac{x_{i j}}{\sum_{p=1}^{m} x_{p j}} i=1,2, \ldots, m \text { and } j=1,2, \ldots, n
$$

$R=\left[r_{i j}\right]_{m \times n}$ normalized decision matrix is obtained.

Table 6: Criteria parameters

Tabela 6: Merila parametrov

\begin{tabular}{|c|c|c|c|c|c|c|c|c|c|c|c|}
\hline Criterion & $\begin{array}{c}\text { Abrasive } \\
(\mathrm{mesh})\end{array}$ & $\begin{array}{c}\text { Load } \\
(\mathrm{N})\end{array}$ & $\begin{array}{c}\text { Speed } \\
(\mathrm{r} / \mathrm{min})\end{array}$ & Criterion & $\begin{array}{c}\text { Abrasive } \\
(\mathrm{mesh})\end{array}$ & $\begin{array}{c}\text { Load } \\
(\mathrm{N})\end{array}$ & $\begin{array}{c}\text { Speed } \\
(\mathrm{r} / \mathrm{min})\end{array}$ & Criterion & $\begin{array}{c}\text { Abrasive } \\
(\mathrm{mesh})\end{array}$ & $\begin{array}{c}\text { Load } \\
(\mathrm{N})\end{array}$ & $\begin{array}{c}\text { Speed } \\
(\mathrm{r} / \mathrm{min})\end{array}$ \\
\hline $\mathrm{C}_{1}$ & 800 & 0.5 & 45 & $\mathrm{C}_{10}$ & 1000 & 0.5 & 45 & $\mathrm{C}_{19}$ & 1200 & 0.5 & 45 \\
\hline $\mathrm{C}_{2}$ & 800 & 0.5 & 90 & $\mathrm{C}_{11}$ & 1000 & 0.5 & 90 & $\mathrm{C}_{20}$ & 1200 & 0.5 & 90 \\
\hline $\mathrm{C}_{3}$ & 800 & 0.5 & 140 & $\mathrm{C}_{12}$ & 1000 & 0.5 & 140 & $\mathrm{C}_{21}$ & 1200 & 0.5 & 140 \\
\hline $\mathrm{C}_{4}$ & 800 & 1 & 45 & $\mathrm{C}_{13}$ & 1000 & 1 & 45 & $\mathrm{C}_{22}$ & 1200 & 1 & 45 \\
\hline $\mathrm{C}_{5}$ & 800 & 1 & 90 & $\mathrm{C}_{14}$ & 1000 & 1 & 90 & $\mathrm{C}_{23}$ & 1200 & 1 & 90 \\
\hline $\mathrm{C}_{6}$ & 800 & 1 & 140 & $\mathrm{C}_{15}$ & 1000 & 1 & 140 & $\mathrm{C}_{24}$ & 1200 & 1 & 140 \\
\hline $\mathrm{C}_{7}$ & 800 & 1.5 & 45 & $\mathrm{C}_{16}$ & 1000 & 1.5 & 45 & $\mathrm{C}_{25}$ & 1200 & 1.5 & 45 \\
\hline $\mathrm{C}_{8}$ & 800 & 1.5 & 90 & $\mathrm{C}_{17}$ & 1000 & 1.5 & 90 & $\mathrm{C}_{26}$ & 1200 & 1.5 & 90 \\
\hline $\mathrm{C}_{9}$ & 800 & 1.5 & 140 & $\mathrm{C}_{18}$ & 1000 & 1.5 & 140 & $\mathrm{C}_{27}$ & 1200 & 1.5 & 140 \\
\hline
\end{tabular}




\section{MATERIALI IN TEHNOLOGIJE/MATERIALS AND TECHNOLOGY (1967-2017) - 50 LET/50 YEARS}

Y. KÜÇÜK et al.: EVALUATION OF THE WEAR BEHAVIOR OF NITRIDE-BASED PVD COATINGS USING DIFFERENT ...

Step 2:

With the following Equation (3):

$$
e_{j}=-\frac{1}{\ln m} \sum_{i=1}^{m} r_{i j} \ln r_{i j} \quad j=1,2, \ldots, n
$$

entropy value of each criterion is found. Here, $e_{j}$ is the entropy value of the $j$ the criterion.

Step 3:

The weighting values of the criteria are assigned with Equation (4):

$$
W_{j}=\frac{1-e_{j}}{\sum_{p=1}^{n}\left(1-e_{p}\right)} j=1,2, \ldots, n
$$

It is apparent that $\sum_{j=1}^{n} W_{j}=1$

\section{RESULTS AND DISCUSSION}

In this study, TOPSIS, MAUT and CP methods among the MDCM methods are used with the wear results obtained from the conducted micro-abrasion tests for the selection of the most suitable coating material, and afterwards the solutions proposed by each method are compared.

First, the criteria were weighted through the implementation of the Entropy method on the decision matrix
(Table 7) consisting of the test results obtained from the micro-abrasion tests conducted in accordance with the test parameters given in Table 3, and then the analyses were carried out for each of the TOPSIS, MAUT and CP methods, as a means for the selection of the most suitable coating material. The resulting solutions were listed in descending order (from the most to the least suitable) by a comparative evaluation.

The criterion weights obtained with the Entropy method are given in Table $\mathbf{8}$.

The criteria weights were objectively determined with the Entropy method. The criteria weights calculated using the Entropy method are given in Table 8 . According to these results, the criterion weights of the $26^{\text {th }}, 22^{\text {nd }}, 25^{\text {th }}$ and $19^{\text {th }}$ criteria were found to be higher than the other criteria. This arises from the fact that the $7^{\text {th }}$ alternative Uncoated sample and $1^{\text {st }}$ alternative $\mathrm{CrN}$ coating result in relatively higher wear rates, whereas $\mathrm{N}+\mathrm{CrN}$, TiAlN and TiN coatings result in lower wear rates. Consequently, the coatings providing lower wear rates under these criteria are favored over the other coatings. Other criterion weights generally had approximate values.

\subsection{Analysis using TOPSIS method}

The Technique for order preference by similarity to ideal solution (TOPSIS) method developed by C. - L. Hwang and K. Yoon ${ }^{28}$ is based on the basic concept of

Table 7: The decision matrix for coating-material selection

\begin{tabular}{|c|c|c|c|c|c|c|c|c|c|c|c|c|c|c|}
\hline Material & $\mathrm{C} 1$ & $\mathrm{C} 2$ & $\mathrm{C} 3$ & $\mathrm{C} 4$ & C5 & C6 & C7 & $\mathrm{C} 8$ & C9 & $\mathrm{C} 10$ & C11 & $\mathrm{C} 12$ & $\mathrm{C} 13$ & \\
\hline $\mathrm{CrN}$ & 0.0097 & 0.0134 & 0.0135 & 0.0149 & 0.0195 & 0.0221 & 0.0169 & 0.0226 & 0.0267 & 0.0071 & 0.0047 & 0.0044 & 0.0050 & \\
\hline $\mathrm{N}+\mathrm{CrN}$ & 0047 & 0.0061 & 0.0066 & 0.0073 & 0.0099 & 0.0106 & 0.0104 & 0.0096 & 0.0094 & 0.0016 & 0.0013 & 0.0055 & 0.0078 & \\
\hline N+TiAlN & 0.0060 & 0.0071 & 0.0074 & 0.0055 & 0.0067 & 0.0077 & 0.0043 & 0.0067 & 0.0123 & 0.0031 & 0.0079 & 0.0020 & 0.0054 & \\
\hline $\mathrm{N}+\mathrm{TiN}$ & 0.0042 & 0.0060 & 0.0093 & 0.0085 & 0.0129 & 0.0161 & 0.0088 & 0.0185 & 0.0189 & 0.0015 & 0.0037 & 0.0059 & 0.0026 & \\
\hline TiAlN & 0030 & 0.0050 & 0.0073 & 0.0059 & 0.0119 & 0.0111 & 0.0073 & 0.0130 & 0.0190 & 0.0013 & 0.0024 & 0.0075 & 0.00 & \\
\hline TiN & 0041 & 0.0059 & 0.0083 & 0.0070 & 0.0093 & 0.0130 & 0.0074 & 0.0156 & 0.010 & 0.0042 & 0.0061 & 0.0065 & 0.00 & \\
\hline Uncoated & 0.0094 & 0.0147 & 0.0147 & 0.0220 & 0.0214 & 0.0228 & 0.0196 & 0.0220 & 0.0267 & 0.0081 & 0.0102 & 0.0122 & 0.0117 & \\
\hline Material & C14 & $\mathrm{C} 15$ & $\mathrm{C} 16$ & C17 & C18 & C19 & $\mathrm{C} 20$ & $\mathrm{C} 21$ & $\mathrm{C} 22$ & $\mathrm{C} 23$ & $\mathrm{C} 24$ & $\mathrm{C} 25$ & C26 & $\mathrm{C} 27$ \\
\hline $\mathrm{CrN}$ & 0.0055 & 0.0072 & 0.0100 & 0.0064 & 0.0118 & 0.0021 & 0.0024 & 0.0013 & 0.0020 & 0.0021 & 0.0022 & 0.0024 & 0.0021 & 0.0029 \\
\hline $\mathrm{N}+\mathrm{CrN}$ & & 0.0093 & 0.0051 & 0.0036 & 0.0094 & 0.0005 & 0.0006 & 0.0009 & & & & & & \\
\hline $\mathrm{N}+\mathrm{TiAlN}$ & 0.0092 & 0.0026 & 0.0054 & 0.0068 & 0.0050 & 0.0003 & 0.0008 & 0.0005 & 0.0004 & 0.0015 & 0.0007 & 0.0009 & 0.0010 & 0.0005 \\
\hline $\mathrm{N}+\mathrm{TiN}$ & 0.0018 & 0.0117 & 0.0065 & 0.0016 & 0.0064 & 0.0009 & 0.0011 & 0.0015 & 0.0011 & 0.0014 & 0.0009 & 0.0012 & 0.0017 & 0.0012 \\
\hline TiAlN & 0.0056 & 0.0054 & 0.0012 & 0.0028 & 0.0034 & 0.0015 & & & & & & 0.0004 & 0.0004 & 0.0007 \\
\hline TiN & 0.0045 & 0.0011 & 0.0072 & 0.0092 & 0.0090 & 0.0004 & 0.0009 & 0.0012 & 0.0005 & & & & & 0.0008 \\
\hline Uncoated & 0.0139 & 0.0246 & 0.0164 & 0.0166 & 0.0255 & 0.0048 & 0.0049 & 0.0024 & 0.0053 & 0.0030 & 0.0040 & 0.0055 & 0.0067 & 0.0027 \\
\hline
\end{tabular}

Tabela 7: Matrica odločitev pri izbiri materiala nanosa

Table 8: The criterion weights obtained using the entropy method

Tabela 8: Kriterijske uteži, dobljene z metodo entropije

\begin{tabular}{|c|c|c|c|c|c|c|c|c|c|}
\hline Criterion & C1 & C2 & C3 & C4 & C5 & C6 & C7 & C8 & C9 \\
\hline Weight & 0.0158 & 0.0163 & 0.0082 & 0.0245 & 0.0131 & 0.0120 & 0.0203 & 0.0126 & 0.0131 \\
\hline Criterion & C10 & C11 & C12 & C13 & C14 & C15 & C16 & C17 & C18 \\
\hline Weight & 0.0403 & 0.0297 & 0.0196 & 0.0279 & 0.0259 & 0.0571 & 0.0321 & 0.0414 & 0.0357 \\
\hline Criterion & C19 & C20 & C21 & C22 & C23 & C24 & C25 & C26 & C27 \\
\hline Weight & 0.0758 & 0.0616 & 0.0219 & 0.0866 & 0.0353 & 0.0540 & 0.0790 & 0.0922 & 0.0482 \\
\hline
\end{tabular}




\section{MATERIALI IN TEHNOLOGIJE/MATERIALS AND TECHNOLOGY (1967-2017) - 50 LET/50 YEARS}

\section{Y. KÜÇÜK et al.: EVALUATION OF THE WEAR BEHAVIOR OF NITRIDE-BASED PVD COATINGS USING DIFFERENT ...}

the selection of the alternative closest to ideal solution and the farthest to anti-ideal solution. The consecutive stages of this method are as follows: ${ }^{28,56}$

Step 1: Constructing the normalized decision matrix: with the following Equation (5):

$$
r_{i j}=\frac{x_{i j}}{\sqrt{\sum_{p=1}^{m}\left(x_{p j}\right)^{2}}} i=1,2, \ldots, m \text { and } j=1,2, \ldots, n
$$

Normalized decision matrix $R=\left[r_{i j}\right]$ is obtained.

Step 2: Constructing the weighted normalized decision matrix, with the following Equation (6):

$$
v_{i j}=w_{j} r_{i j} \quad i=1,2, \ldots, m \text { and } j=1,2, \ldots, n
$$

Normalized decision matrix $V=\left[v_{i j}\right]_{m \times n}$ is obtained.

Here, $w_{j}: j$-th criterion's weight value obtained with the entropy method.

Step 3: Determination of ideal and negative-ideal solutions:

If the two artificial solutions $A^{*}$ (ideal solution) and $A^{-}$(negative-ideal solution) are defined as follows:

$$
\begin{aligned}
& A^{*}=\left\{\left(\max _{i} v_{i j} \mid j \in J\right),\left(\min _{i} v_{i j} \mid j \in J^{\prime}\right) \mid i=1,2, \ldots, m\right\} \\
& =\left\{v_{1}^{*}, v_{2}^{*}, \ldots, v_{j}^{*}, \ldots v_{n}^{*},\right\} \\
& A^{-}=\left\{\left(\min _{i} v_{i j} \mid j \in J\right),\left(\max _{i} v_{i j} \mid j \in J^{\prime}\right) \mid i=1,2, \ldots, m\right\} \\
& =\left\{v_{1}^{-}, v_{2}^{-}, \ldots, v_{j}^{-}, \ldots v_{n}^{-},\right\}
\end{aligned}
$$

here,

$J=\{j=1,2, \ldots, n \mid$ in case of benefit criterion $\}$

$J^{\prime}=\{j=1,2, \ldots, n \mid$ in case of cost criterion $\}$

Step 4: Calculation of the separation measure:
Each alternative's measure of separation from the ideal solution $S_{i^{*}}$ and from the negative-ideal solution $S_{i^{-}}$, is given as follows:

$$
\begin{aligned}
& S_{i^{*}}=\sqrt{\sum_{j=1}^{n}\left(v_{i j}-v_{j}^{*}\right)^{2}}, i=1,2, \ldots, m \\
& S_{i^{-}}=\sqrt{\sum_{j=1}^{n}\left(v_{i j}-v_{j}^{-}\right)^{2}}, i=1,2, \ldots, m
\end{aligned}
$$

Step 5: Calculation of the relative proximity to the ideal solution:

The relative proximity to the $i$-th alternative to the ideal solution $\left(A^{*}\right)$ is defined as follows:

$$
C_{i^{*}}=S_{i^{-}}\left(S_{i^{*}}-S_{i^{-}}\right), 0<C_{i^{*}}<1, i=1,2, \ldots, m
$$

Step 6: Performing the decision ranking: The decision ranking of the alternatives is performed in accordance with the descending order of $C_{i^{*}}$ values.

The weighted and normalized decision matrix, related to the analysis conducted in accordance with the steps defined in the TOPSIS method, is given in Table 9. Ideal and anti-ideal solutions obtained using Equations (7) and (8), are given in Table 10. As indicated in the table, the highest $C_{i^{*}}$ valued alternative stands for the best selection in the TOPSIS method.

Positive and negative separation measures given in Table 11 and relative proximities to the ideal solution are calculated respectively with Equations (9), (10) and (11). Also, the ranking of the coating materials based on the relative proximities to ideal solution are given in Table 11. According to this ranking, TiAlN is qualified

\begin{tabular}{|c|c|c|c|c|c|c|c|c|c|c|c|c|c|c|}
\hline Material & $\mathrm{C} 1$ & $\mathrm{C} 2$ & C3 & $\mathrm{C} 4$ & C5 & C6 & C7 & C8 & C9 & C10 & $\mathrm{C} 11$ & $\mathrm{C} 12$ & $\mathrm{C} 13$ & \\
\hline $\mathrm{CrN}$ & 0.0091 & 0.0091 & 0.0042 & 0.0118 & 0.0069 & 0.0063 & 0.0109 & 0.0066 & 0.0070 & 0.0235 & 0.0089 & 0.0047 & 0.0083 & \\
\hline $\mathrm{N}+\mathrm{CrN}$ & 0.0044 & 0.0041 & 0.0020 & 0.0058 & 0.0035 & 0.0030 & 0.0067 & 0.0028 & 0.0024 & 0.0053 & 0.0024 & 0.0059 & 0.0130 & \\
\hline N+TiAlN & 0.0056 & 0.0048 & 0.0023 & 0.0044 & 0.0024 & 0.0022 & 0.0028 & 0.0020 & 0.0032 & 0.0102 & 0.0150 & 0.0021 & 0.0091 & \\
\hline $\mathrm{N}+\mathrm{TiN}$ & 0.0039 & 0.0041 & 0.0029 & 0.0068 & 0.0045 & 0.0046 & 0.0057 & 0.0054 & 0.0049 & 0.0048 & 0.0069 & 0.0063 & 0.0044 & \\
\hline TiAlN & 0.0028 & 0.0034 & 0.0023 & 0.0047 & 0.0042 & 0.0032 & 0.0047 & 0.0038 & 0.0050 & 0.0042 & 0.0045 & 0.0080 & 0.0032 & \\
\hline TiN & & 0.0040 & 0.0026 & 0.0056 & 0.003 & 0.0037 & 0.0048 & 0.0045 & 0.00 & 0.0137 & 0.01 & 0.0070 & 0.0065 & \\
\hline Uncoated & 0.0088 & 0.0100 & 0.0046 & 0.0175 & 0.0075 & 0.0066 & 0.0127 & 0.0064 & 0.0070 & 0.0267 & 0.0192 & 0.0131 & 0.0196 & \\
\hline Material & C14 & $\mathrm{C} 15$ & $\mathrm{C} 16$ & $\mathrm{C} 17$ & C18 & C19 & $\mathrm{C} 20$ & $\mathrm{C} 21$ & $\mathrm{C} 22$ & $\mathrm{C} 23$ & $\mathrm{C} 24$ & $\mathrm{C} 25$ & $\mathrm{C} 26$ & $\mathrm{C} 27$ \\
\hline $\mathrm{CrN}$ & 0.0072 & 0.0135 & 0.0141 & 0.0121 & 0.0132 & 0.0289 & 0.0257 & 0.0080 & 0.0292 & 0.0171 & 0.0244 & 0.0304 & 0.0259 & 0.0325 \\
\hline $\mathrm{N}+\mathrm{CrN}$ & 0.0076 & 0.0175 & 0.0072 & 0.0069 & 0.0105 & 0.0065 & 0.0062 & 0.0053 & 0.0115 & 0.0046 & 0.0069 & 0.0058 & 0.0037 & \\
\hline N+TiAlN & 0.0119 & 0.0048 & 0.0075 & 0.0130 & 0.0055 & 0.0038 & 0.0082 & 0.0032 & 0.0055 & 0.0127 & 0.0073 & 0.0111 & 0.0122 & 0.0051 \\
\hline $\mathrm{N}+\mathrm{TiN}$ & 0.0023 & 0.0220 & 0.0092 & 0.0030 & 0.0070 & 0.0128 & 0.0112 & 0.0093 & 0.0159 & 0.0114 & 0.0104 & 0.0155 & 0.0209 & 0.0133 \\
\hline TiAlN & 0.0073 & 0.0101 & 0.0017 & 0.0053 & 0.0037 & 0.0206 & 0.0062 & 0.0036 & 0.0055 & 0.0030 & 0.0082 & 0.0051 & 0.0044 & 0.0073 \\
\hline TiN & 0.0058 & 0.0020 & 0.0102 & 0.0176 & 0.0100 & 0.0048 & 0.0096 & 0.0073 & 0.0069 & 0.0059 & 0.0066 & 0.0070 & 0.0088 & \\
\hline Uncoated & 0.0181 & 0.0464 & 0.0231 & 0.0316 & 0.0283 & 0.0651 & 0.0526 & 0.0149 & 0.0784 & 0.0243 & 0.0447 & 0.0696 & 0.0845 & 0.0302 \\
\hline
\end{tabular}
as the best coating material owing to its excellent performance, which is followed by $\mathrm{N}+\mathrm{CrN}$, TiN and $\mathrm{N}+\mathrm{TiAlN}$ with similar performance values. $\mathrm{N}+\mathrm{TiN}$ and $\mathrm{CrN}$ resulted in low performance values, whereas the uncoated material resulted in the worst performance value.

Table 9: Weighted normalized decision matrix

Tabela 9: Pretehtana normalizirana matrica odločitev 


\section{MATERIALI IN TEHNOLOGIJE/MATERIALS AND TECHNOLOGY (1967-2017) - 50 LET/50 YEARS}

Y. KÜÇÜK et al.: EVALUATION OF THE WEAR BEHAVIOR OF NITRIDE-BASED PVD COATINGS USING DIFFERENT ...

Table 10: Ideal and anti-ideal solutions

Tabela 10: Idealne in neidealne rešitve

\begin{tabular}{|c|c|c|c|c|c|c|c|c|c|}
\hline Criterion & C1 & C2 & C3 & C4 & C5 & C6 & C7 & C8 & C9 \\
\hline$A^{*}$ & 0.0028 & 0.0034 & 0.0020 & 0.0044 & 0.0024 & 0.0022 & 0.0028 & 0.0020 & 0.0024 \\
\hline$A^{-}$ & 0.0091 & 0.0100 & 0.0046 & 0.0175 & 0.0075 & 0.0066 & 0.0127 & 0.0066 & 0.0070 \\
\hline Criterion & $\mathrm{C} 10$ & $\mathrm{C} 11$ & $\mathrm{C} 12$ & $\mathrm{C} 13$ & $\mathrm{C} 14$ & $\mathrm{C} 15$ & $\mathrm{C} 16$ & $\mathrm{C} 17$ & $\mathrm{C} 18$ \\
\hline$A^{*}$ & 0.0042 & 0.0024 & 0.0021 & 0.0032 & 0.0023 & 0.0020 & 0.0017 & 0.0030 & 0.0037 \\
\hline$A^{-}$ & 0.0267 & 0.0192 & 0.0131 & 0.0196 & 0.0181 & 0.0464 & 0.0231 & 0.0316 & 0.0283 \\
\hline Criterion & $\mathrm{C} 19$ & $\mathrm{C} 20$ & $\mathrm{C} 21$ & $\mathrm{C} 22$ & $\mathrm{C} 23$ & $\mathrm{C} 24$ & $\mathrm{C} 25$ & $\mathrm{C} 26$ & $\mathrm{C} 27$ \\
\hline$A^{*}$ & 0.0038 & 0.0062 & 0.0032 & 0.0055 & 0.0030 & 0.0066 & 0.0051 & 0.0037 & 0.0044 \\
\hline$A^{-}$ & 0.0651 & 0.0526 & 0.0149 & 0.0784 & 0.0243 & 0.0447 & 0.0696 & 0.0845 & 0.0325 \\
\hline
\end{tabular}

Table 11: Positive and negative separation measures, relative proximities to the ideal solution and the ranking

Tabela 11: Pozitivni in negativni ukrepi ločevanja, relativni približki idealni rešitvi in razvrstitev

\begin{tabular}{|c|c|c|c|c|}
\hline Material & S+ & S- & C+ & Sýra \\
\hline CrN & 0.0724 & 0.1104 & 0.6039 & 6 \\
\hline N+CrN & 0.0234 & 0.1632 & 0.8747 & 2 \\
\hline N+TiAlN & 0.0262 & 0.1610 & 0.8602 & 4 \\
\hline N+TiN & 0.0371 & 0.1433 & 0.7946 & 5 \\
\hline TiAlN & 0.0212 & 0.1648 & 0.8861 & 1 \\
\hline TiN & 0.0255 & 0.1620 & 0.8640 & 3 \\
\hline Uncoated & 0.1742 & 0.0023 & 0.0132 & 7 \\
\hline
\end{tabular}

\subsection{Analysis using MAUT method}

According to the basic principle of MAUT (Multiple Attribute Utility Theory) method, there is an $U$ utility function with a real value, defined over the set of suitable alternatives, and the decision maker maximizes this. ${ }^{58}$ The procedure followed in the MAUT method is defined in 4 steps: ${ }^{59-60}$
Step 1: Utility values are determined according to the benefit criteria and the normalized values $r_{i j}$ are calculated using these values:

$$
r_{i j}=\frac{x_{i j}-l_{l}^{-}}{u_{j}^{+}-l_{l}^{-}}, u_{j}^{+}=\max _{i} x_{i j}, l_{j}^{-}=\min _{i} x_{i j}
$$

Similarly, the utility values are also determined based on the cost criterion, and normalized values $r_{i j}$ are calculated accordingly:

$$
r_{i j}=\frac{u_{l}^{+}-x_{i j}}{u_{j}^{+}-l_{l}^{-}}, u_{j}^{+}=\max _{i} x_{i j}, l_{j}^{-}=\min _{i} x_{i j}
$$

Step 2: Weighted sum of $r_{i j}$ values gives the total utility value.

$$
U_{i}=\sum_{j=1}^{n} w_{j} r_{i j}
$$

Step 3: Decision ranking is performed. The alternative with the highest total utility value is deemed the best alternative.

The single-attribute utility function values of the alternatives calculated with MAUT method based on the criteria, are given in Table $\mathbf{1 2}$.

MAUT multi-attribute utility function values and their ranking are given in Table 13. As shown in Table

\begin{tabular}{|c|c|c|c|c|c|c|c|c|c|c|c|c|c|c|}
\hline Material & $\mathrm{C} 1$ & $\mathrm{C} 2$ & C3 & $\mathrm{C} 4$ & C5 & C6 & C7 & C8 & C9 & C10 & $\mathrm{C} 11$ & C12 & C13 & \\
\hline $\mathrm{CrN}$ & 0.0000 & 0.1299 & 0.1556 & 0.4352 & 0.1283 & 0.0498 & 0.1777 & 0.0000 & 0.0000 & 0.1428 & 0.6139 & 0.7683 & 0.6856 & \\
\hline $\mathrm{N}+\mathrm{CrN}$ & 0.7483 & .8835 & 1.0000 & 0.8920 & 0.7841 & 0.8094 & 0.6014 & 0.8183 & & & 1.0000 & 0.6587 & 0.3997 & \\
\hline N+TiAlN & 0.5519 & 7813 & 8990 & 1.0000 & 1.0000 & 1.0000 & 1.0000 & 1.0000 & 0.8310 & .7342 & 0.2495 & 1.0000 & 0.6384 & \\
\hline $\mathrm{N}+\mathrm{TiN}$ & 0.8212 & 0.8924 & 0.6653 & 0.8215 & 0.5769 & 0.4445 & 0.7070 & 0.2588 & 0.4521 & 0.9742 & 0.7299 & 0.6205 & 0.9282 & \\
\hline TiAlN & 1.0000 & 1.0000 & 0.9083 & 0.9812 & 0.6450 & 0.7784 & 0.8047 & 0.6033 & 0.4462 & 1.0000 & 0.8771 & 0.4622 & 1.0000 & \\
\hline TiN & 0.8332 & 0.9034 & 0.7956 & 0.9099 & 0.8235 & 0.6514 & 0.7982 & 0.4395 & 0.9160 & 0.5800 & 0.4557 & 0.5562 & 0.7969 & \\
\hline Uncoated & 0.0450 & 0.0000 & 0.0000 & 0.0000 & 0.0000 & 0.0000 & 0.0000 & 0.0399 & 0.0000 & 0.0000 & 0.0000 & 0.0000 & 0.0000 & \\
\hline Material & C14 & C15 & C16 & $\mathrm{C} 17$ & C18 & C19 & $\mathrm{C} 20$ & $\mathrm{C} 21$ & $\mathrm{C} 22$ & $\mathrm{C} 23$ & $\mathrm{C} 24$ & $\mathrm{C} 25$ & C26 & $\mathrm{C} 27$ \\
\hline $\mathrm{CrN}$ & 0.6906 & 0.7401 & 0.4203 & 0.6811 & 0.6160 & 0.5904 & 0.5791 & 0.5917 & 0.6755 & 0.3393 & 0.5349 & 0.6074 & 0.7250 & 0.0000 \\
\hline $\mathrm{N}+\mathrm{CrN}$ & 0.6669 & 0.6501 & 0.7451 & & 0.7248 & & & & & 0.9229 & 0.9944 & 0.9889 & 1.0000 & 1.0000 \\
\hline $\mathrm{N}+\mathrm{TiAlN}$ & 0.3921 & 0.9361 & & & 0.9275 & 1.0000 & & 1.0000 & & & & 0.9071 & 0.8948 & 0.9741 \\
\hline $\mathrm{N}+\mathrm{TiN}$ & 1.0000 & 0.5491 & 0.6526 & 1.0000 & 0.8645 & 0.8520 & 0.8925 & 0.4780 & 0.8575 & 0.6050 & 0.9001 & 0.8378 & 0.7873 & 0.6851 \\
\hline TiAlN & 0.6856 & 0.8163 & 1.0000 & 0.9198 & 1.0000 & 0.7259 & 1.0000 & 0.9622 & 1.0000 & 1.0000 & 0.9589 & 1.0000 & 0.9915 & 0.8953 \\
\hline TiN & 0.7755 & 1.0000 & 0.6055 & 0.4903 & 0.7436 & 0.9834 & 0.9266 & 0.6537 & 0.9804 & 0.8625 & 1.0000 & 0.9698 & 0.9372 & 0.8410 \\
\hline Uncoated & 0.0000 & 0.0000 & 0.0000 & 0.0000 & 0.0000 & 0.0000 & 0.0000 & 0.0000 & 0.0000 & 0.0000 & 0.0000 & 0.0000 & 0.0000 & 0.0822 \\
\hline
\end{tabular}

Table 12: MAUT single-attribute utility function values

Tabela 12: Posamezni MAUT-atributi vrednosti funkcije koristnosti 
13, TiAlN takes the first place with its superior performance, followed by $\mathrm{N}+\mathrm{CrN}, \mathrm{N}+\mathrm{TiAlN}$ and TiN with similar performance values. $\mathrm{N}+\mathrm{TiN}, \mathrm{CrN}$ and especially uncoated material exhibited significantly low performances, as the highest total utility valued alternative stands for the best selection.

Table 13: MAUT Multi-utility function and the ranking Tabela 13: MAUT Večvrednostna funkcija in razvrstitev

\begin{tabular}{|c|c|c|}
\hline Material & Multi utility values & Ranking \\
\hline CrN & 0.509431 & 6 \\
\hline N+CrN & 0.879946 & 2 \\
\hline N+TiAlN & 0.860277 & 3 \\
\hline N+TiN & 0.784909 & 5 \\
\hline TiAlN & 0.909513 & 1 \\
\hline TiN & 0.841247 & 4 \\
\hline Uncoated & 0.005178 & 7 \\
\hline
\end{tabular}

\subsection{Analysis using CP method}

$\mathrm{CP}$ (Compromise Programming) is a MCDM method developed in the 1970 s by M. Zelen ${ }^{61}$ and P. - L. Yu. ${ }^{62}$ This method is based on minimization of the distance to the ideal point $f^{*}$. The $L_{p}$ metric is used for the calculation of distance. The method can be summarized as follows: ${ }^{63-66}$

Step 1: Ideal point $f^{*}$ and anti-ideal point $f_{*}$ are established.

$$
f^{*} \equiv f_{1}^{*}, f_{2}^{*}, \ldots, f_{n}^{*}, f_{*} \equiv f_{1^{*}}, f_{2^{*}}, \ldots, f_{n^{*}}
$$

here,

$$
\begin{aligned}
f_{j}^{*} & = \begin{cases}\max _{i=1,2, \ldots, m}\left\{\mathrm{x}_{\mathrm{ij}}\right\} & j \cdot \text { criterion utility } \\
\min _{i=1,2, \ldots, m}\left\{\mathrm{x}_{\mathrm{ij}}\right\} & j \cdot \text { criterion cost }\end{cases} \\
f_{j^{*}} & = \begin{cases}\min _{i=1,2, \ldots, m}\left\{\mathrm{x}_{\mathrm{ij}}\right\} & j \cdot \text { criterion utility } \\
\max _{i=1,2, \ldots, m}\left\{\mathrm{x}_{\mathrm{ij}}\right\} & j \cdot \text { criterion cost }\end{cases}
\end{aligned}
$$

here, $x_{i j}$ : is the success value of the $i$-th alternative according to the $j$-th criterion. $i=1,2, \ldots, m, j=1,2, \ldots, n$.

Step 2: The distance to the ideal point is minimized:

$$
\min L_{p}=\left\lceil\sum_{j=1}^{n} W_{j}\left(\frac{f_{j}^{*}-f_{j}\left(x_{i}\right)}{f_{j}^{*}-f_{j^{*}}}\right)^{p}\right\rceil^{1 / p}, i=1,2, \ldots, m
$$

Step 3: The alternative giving the minimal value is the best alternative.

$L_{1}, L_{2}$ and $L_{\infty}$ are, respectively, named as the Manhattan, Euclidean and Tchebycheff metrics.

The optimal values obtained using the $\mathrm{CP}$ method and the ranking are shown in Table 14. Given that in the $\mathrm{CP}$ method the alternative giving the lowest optimal value is the best alternative; TiAlN may be considered to have shown the best performance by far, as the highest total utility valued alternative stands for the best selection. $\mathrm{N}+\mathrm{CrN}, \mathrm{N}+\mathrm{TiAlN}$ and TiN materials underperformed compared to the performance values of TiAlN.

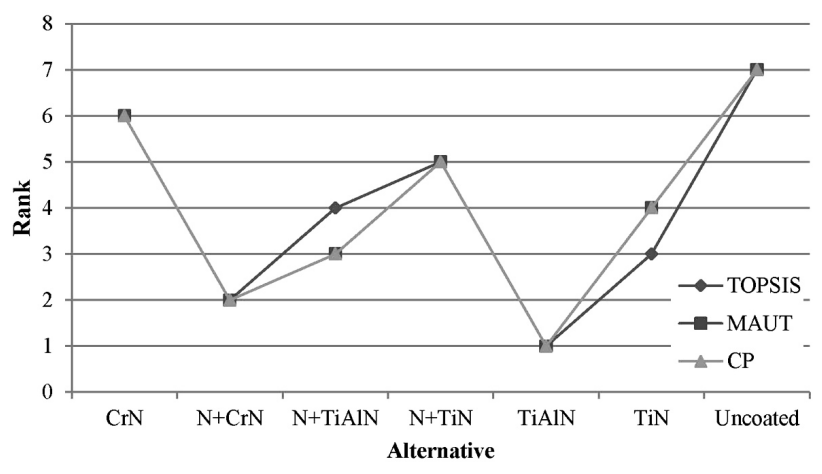

Figure 3: Ranking of the alternatives obtained with MCDM methods Slika 3: Razvrstitev alternativnih variant, dobljenih z MCDM metodami

The performance values of $\mathrm{N}+\mathrm{TiN}, \mathrm{CrN}$ and the uncoated materials lined up at the bottom of the performance list.

Table 14: CP optimal values and the ranking Tabela 14: CP optimalne vrednosti in razvrstitev

\begin{tabular}{|c|c|c|}
\hline Material & Optimal value & Rank \\
\hline CrN & 0.269379 & 6 \\
\hline N+CrN & 0.070013 & 2 \\
\hline N+TiAlN & 0.080999 & 3 \\
\hline N+TiN & 0.120416 & 5 \\
\hline TiAlN & 0.055632 & 1 \\
\hline TiN & 0.089914 & 4 \\
\hline Uncoated & 0.543521 & 7 \\
\hline
\end{tabular}

The rankings obtained using the TOPSIS, MAUT and $\mathrm{CP}$ methods are shown in Figure 3. As seen in the figure, the MAUT and $\mathrm{CP}$ methods produced the identical ranking of the alternatives, whereas there is a slight deviation in the ranking obtained with the TOPSIS method. However, all the methods indicate that TiAlN is the best material, followed by $\mathrm{N}+\mathrm{CrN}$. $\mathrm{CrN}$ and the uncoated materials displayed the best performances, according to all the MCDM methods implemented in the study.

\section{CONCLUSIONS}

In this study, abrasive wear tests were conducted using the micro-abrasion wear technique on $\mathrm{TiN}, \mathrm{CrN}$ and AlTiN coatings, which were deposited on nitrided and non-nitrided substrates with the PVD technique, then the measured wear values were used so as to determine the best coating selection through analyses with each of the TOPSIS, MAUT and CP methods among the MCDM techniques. The most suitable coating types, according to each method, were determined and comparatively evaluated. The obtained results are summarized as follows:

- According to the TOPSIS method TiAlN was determined to be the coating with the best performance; which was followed by $\mathrm{N}+\mathrm{CrN}$, TiN and $\mathrm{N}+\mathrm{TiAlN}$, respectively. The $\mathrm{N}+\mathrm{TiN}$ and $\mathrm{CrN}$ coatings under- 
performed compared to other coatings; however, the uncoated material displayed the worst performance, with a dramatic decline compared to all the coated materials.

- According to the MAUT method, TiAlN exhibited the best performance. Other coatings were ranked as $\mathrm{N}+\mathrm{CrN}, \mathrm{N}+\mathrm{TiAlN}$ and TiN, respecively. N+TiN, CrN and especially the uncoated material displayed remarkable underperformances.

- The CP and MAUT methods produced the same ranking of alternatives. In the TOPSIS method only $\mathrm{N}+\mathrm{TiAlN}$ and TiN shifted places in the ranking differently from the $\mathrm{CP}$ and MAUT methods. However, all the methods indicate that TiAlN is the best material, which is followed by $\mathrm{N}+\mathrm{CrN}$. Again, the $\mathrm{CrN}$ and uncoated materials became the alternatives with worse performances according to all the MCDM methods.

- The highest $C_{\mathrm{i}^{*}}$ valued alternative is deemed the best selection in the TOPSIS method. While the highest total utility valued alternative is the best selection for MAUT, in the CP method the shortest distance is favored.

- Increasing the number of MCDM methods could be useful for a comparative analysis of the obtained results in further studies.

\section{Acknowledgements}

The authors would like to acknowledgement the funding support of the Scientific Research Project (BAP) no 2013.1.85. provided by Bartin University Scientific Research Projects Unit. All other support provided by the Engineering Faculty of Bartin University and its staff is also acknowledged.

\section{REFERENCES}

${ }^{1}$ J. Vetter, Vacuum arc coatings for tools: potential and application Surface and Coatings Technology, 76-77 (1995), 719-724, doi:10.1016/0257-8972(95)02499-9

${ }^{2}$ R. J. Rodriguez, J. A. Garcia, A. Medrano, M. Rico, R. Sanchez, R. Martinez, Tribological behaviour of hard coatings deposited by arc-evaporation PVD, Vacuum, 67 (2002), 559-566, doi:10.1016/ s0042-207x(02)00248-8

${ }^{3}$ H. Çalışkan, P. Panjan, S. Paskvale, Monitoring of wear characteristics of TiN and TiAlN coatings at long sliding distances, Tribology Transactions, 57 (2014), 496-502, doi:10.1080/10402004.2014. 884254

${ }^{4}$ M. Vite, M. Moreno-Rios, E. A. G. Hernandez, J. R. LagunaCamacho, A study of the abrasive resistance of sputtered $\mathrm{CrN}$ coatings deposited on AISI 316 and AISI H13 steel substrates using steel particles, Wear, 271 (2011), 1273-1279, doi:10.1016/j.wear. 2011.01.072

${ }^{5}$ P. Panjan, P. Cvahte, M. Čekada, B. Navinšek, I. Urankar, PVD CrN coating for protection of extrusion dies, Vacuum 61 (2001), 241-244, doi:10.1016/s0042-207x(01)00113-0

${ }^{6} \mathrm{H}$. Çalışkan, Effect of test parameters on the micro-abrasion behavior of PVD CrN coatings, Measurement 55 (2014), 444-451, doi:10.1016/j.measurement.2014.05.036
${ }^{7}$ M. F. C. Andrade, R. P. Martinho, F. J. G. Silva, R. J. D. Alexandre, A. P. M. Baptista, Influence of the abrasive particles size in the microabrasion wear tests of TiAlSiN thin coatings, Wear, 267 (2009), 12-18, doi:10.1016/j.wear.2008.12.114

${ }^{8}$ A. Kassman, S. Jacobson, L. Erickson, P. Hedenqvist, M. Olsson, A new test method for the intrinsic abrasion resistance of thin coatings, Surf. Coat. Technol, 50 (1991), 75-84, doi:10.1016/02578972(91)90196-4

${ }^{9}$ X.-Z. Ding, C. T. Bui, X. T. Zeng, Abrasive wear resistance of Ti1-xAlxN hard coatings deposited by a vacuum arc system with lateral rotating cathodes, Surf. Coat. Technol., 203 (2008), 680-684, doi:10.1016/j.surfcoat.2008.08.019

${ }^{10}$ J. C. A. Batista, C. Godoy, A. Matthews, Micro-scale abrasive wear testing of duplex and non-duplex (single-layered) PVD (Ti, Al)N, TiN and $\mathrm{Cr}-\mathrm{N}$ coatings. Tribol. Int., 35 (2002), 363-372, doi:10.1016/s0301-679x(02)00017-8

${ }^{11}$ B. Kurt, Y. Kucuk, M. S. Gok, Microabrasion Wear Behavior of VC and $\mathrm{CrC}$ Coatings Deposited by Thermoreactive Diffusion Technique. Tribology Transactions, 57 (2014), 345-352, doi:10.1080/ 10402004.2014.880538

${ }^{12}$ D. N. Allsopp, I. M. Hutchings, Micro-scale abrasion and scratch response of PVD coatings at elevated temperatures. Wear, 251 (2001), 1308-1314, doi:10.1016/s0043-1648(01)00755-4

${ }^{13}$ K. Bose, R. J. K. Wood, Optimum tests conditions for attaining uniform rolling abrasion in ball cratering tests on hard coatings, Wear, 258 (2005), 322-332,doi:10.1016/j.wear.2004.09.018

${ }^{14}$ H. Çalışkan, A. Erdoğan, P. Panjan, M. S. Gök, A. C. Karaoğlanlı, Microabrasion wear testing of multilayer nanocomposite TiAlSiN/TiSiN/TiAlN hard coatings deposited on AISI H11 steel, Mater. Tehnol., 47 (2013), 563-568

${ }^{15}$ R. P. Martinho, M. F. C. Andrade, F. J. G. Silva, R. J. D. Alexandre, A. P. M. Baptista, Micro-abrasion wear behaviour of TiAlCrSiN nanostructured coatings, Wear, 267 (2009), 1160-1165, doi:10.1016/ j.wear.2008.12.063

${ }^{16}$ D. N. Allsopp, R.I. Trezona, I. M. Hutchings, The effects of ball surface condition in the micro-scale abrasive wear test, Tribol. Lett., 5 (1998), 259-264

${ }^{17}$ F. J. G. Silva, R. B. Casais, R. P. Martinho, A.P.M. Baptista, Role of abrasive material on micro-abrasion wear tests, Wear, 271 (2011), 2632-2639, doi:10.1016/j.wear.2010.11.050

${ }^{18}$ A. Gunen, Y. Kucuk, Y. Er, V. V. Cay, M. Öge, M. S. Gok, Effect of the powder particle size on the wear behaviour of boronized AISI 304 stainless Steel, Materials Testing, 57-5 (2015), 468-473, 10.3139/120.110732

${ }^{19}$ M. H. Korkut, M. S. Gok, A. C. Karaoglanli, Y. Kucuk, Y. Er, A. Erdogan, Effect of Abrasive Grit Size on Wear Behavior of Ceramic Coatings by Micro-Abrasion Test, Mater.Tehnol., 47-6 (2013), 695-699

${ }^{20}$ G. B. Stachowiak, G. W. Stachowiak, J. M. Brandt, Ball-cratering abrasion tests with large abrasive particles, Tribol. Int., 39 (2006), 1-11, doi:10.1016/j.triboint.2004.10.010

${ }^{21}$ K. L. Edwards, Materials influence on design: a decade of development, Mater Des, 32 (2011), 1073-80, doi:10.1016/j.matdes.2010. 10.009

${ }^{22}$ P. Chatterjee, S. Chakraborty, Material selection using preferential ranking methods, Mater. Des., 35 (2012), 384-93, doi:10.1016/ j.matdes.2011.09.027

${ }^{23} \mathrm{H}$. Çalışkan, Selection of boron based tribological hard coatings using multi-criteria decision making methods, Materials \& Design, 50 (2013), 742-749, doi:10.1016/j.matdes.2013.03.059

${ }^{24}$ H. Çalışkan, B. Kurşuncu, C. Kurbanoğlu, Ş. Y. Güven, Material selection for the tool holder working under hard milling conditions using different multi criteria decision making methods, Materials \& Design, 45 (2013), 473-479, doi:10.1016/j.matdes.2012.09.042

${ }^{25}$ E. Triantaphyllou, Multi-criteria decision making methods: A Comparative Study, 2000, Springer, 5-21, doi:10.1007/978-14757-3157-6 


\section{Y. KÜÇÜK et al.: EVALUATION OF THE WEAR BEHAVIOR OF NITRIDE-BASED PVD COATINGS USING DIFFERENT ...}

${ }^{26}$ A. Abrishamchi, A. Ebrahimian, M. Tajrishi, M. A. Mariño, Hon. M. ASCE, Case study: application of multicriteria decision making to urban water supply, Journal of Water Resources Planning and Management, 131 (2005) 4, 326-335, doi:10.1061/(asce)0733-9496(2005) 131:4(326)

${ }^{27}$ A. Chauhan, R.Vaish, Hard coating material selection using multicriteria decision making, Mater Des 44, (2013), 240-245, doi:10.1016/j.matdes.2012.08.003

${ }^{28}$ C. - L. Hwang, K. Yoon, Lecture Notes in Economics and Mathematical Systems: Multiple Attribute Decision Making: Methods and Appllication, Springer Verlag, 1981, doi:10.1007/978-3-642-483189_4

${ }^{29}$ G. Kabir, R. Sadiq, S. Tesfamariam, A review of multi-criteria decision-making methods for infrastructure management, Structure and Infrastructure Engineering, 9 (2014), 1176-1210, doi:10.1080/ 15732479.2013.795978

${ }^{30} \mathrm{~S}$. Opricovic, G. H. Tzeng, Compromise solution by MCDM methods: A comparative analysis of VIKOR and TOPSIS. European Journal of Operational Research, 2 (2004) 156, 445-455, doi:10.1016/s0377-2217(03)00020-1

${ }^{31}$ G. Kabir, R. S. Sumi, Selection of concrete production facility location integrating fuzzy AHP with TOPSIS method. International Journal of Productivity Management and Assessment Technologies, 1 (2012) 1, 40-59, doi:10.4018/ijfsa.2013070104

${ }^{32}$ S. J. Chen, C. L. Hwang, Fuzzy multiple attribute decision making, methods and application. Berlin: SpringerVerlag, (1992), doi:10.1007/978-3-642-46768-4_5

${ }^{33}$ K. P. Yoon, C. L. Hwang, Multiple attribute decision making, Thousand Oaks, CA: Sage Publication, (1995), doi:10.4135/ 9781412985161

${ }^{34}$ A. Pires, N. B. Chang, G. Martinho, An AHP-based fuzzy interval TOPSIS assessment for sustainable expansion of the solid waste management system in Setubal Peninsula, Portuga. Resources, Conservation and Recycling, 56 (2011) 1, 7-21, doi:10.1016/ j.resconrec.2011.08.004

${ }^{35}$ G. Kabir, M. A. A. Hasin, Integrating fuzzy AHP with TOPSIS method for optimal power substation location selection, International Journal of Enterprise Network Management, Advance online publication, (2012b), doi:10.1504/ijleg.2013.059166

${ }^{36}$ B. Benyahia, M. A. Latifi, C. Fonteix, F. Pla, Multicriteria dynamic optimization of an emulsion copolymerization reactor. Computers \& Chemical Engineering, 35 (2011) 12, 2886-2895, doi:10.1016/ s1570-7946(10)28077-x

${ }^{37}$ R. L. Keeny, H. Raiffa, Decision with multiple objectives John Wiley, NY (1976)

${ }^{38}$ R. L. Keeny, H. Raiffa, Decision with multiple objectives: Preferences and value trade-offs, Cambridge University Press (1993), doi:10.1017/cbo9781139174084

${ }^{39}$ S. K. Kim, O. Song, A MAUT approach for selecting a dismantling scenario for the thermal column in KRR-1 Annals of Nuclear Energy, 36 (2009), 145-150, doi:10.1016/j.anucene.2008.11.034

${ }^{40}$ M. Zeleny, Multiple criteria decision making, New York 1982

${ }^{41}$ A. Bárdossy, I. Bogárdi, L. Duckstein, Composite programming as an extension of compromise programming. Mathematics of Multi Objective Optimization (375-408). Wien: Springer Verlag, doi:10.1007/978-3-7091-2822-0_15

${ }^{42}$ A. Elmahdi, K. Kheireldin, A. Hamdy, GIS and multi-criteria evaluation: Robust tools for integrated water resources management, Water International, 31 (2006) 4, 440-447, doi:10.1080/ 02508060608691948

${ }^{43}$ G. Kabir, R. Sadiq, S. Tesfamariam, A review of multi-criteria decision-making methods for infrastructure management, Structure and Infrastructure Engineering, 10 (2014) 9, 1176-1210, doi:10.1080/15732479.2013.795978

${ }^{44}$ N. H. Zardari et al., Weighting Methods and Their Effects on MultiCriteria Decision Making Model Outcomes in Water Resources Management, 2014, Springer, doi:10.1007/978-3-319-12586-2
${ }^{45}$ E. De Las Heras, D. A. Egidi, P. Corengia, D. Gonzalez-Santamaria, A. Garcia-Luis, M. Brizuela et al., Duplex surface treatment of an AISI 316L stainless steel; microstructure and tribological behavior, Surf Coat Technol, 202 (2008), 2945-2954, doi:10.1016/j.surfcoat. 2007.10.037

${ }^{46}$ L. C. Gontijo, R. Machado, S .E. Kuri, L. C. Casteletti, P. A. P. Nascente, Corrosion resistance of the layers formed on the surface of plasma-nitrided AISI 304L steel. Thin Solid Films, 515 (2006), 1093-6, doi:10.1016/j.tsf.2006.07.075

${ }^{47} \mathrm{~T}$., Wierzchon Structure and properties of multicomponent and composite layers produced by combined surface engineering methods. Surf Coat Technol, 180, 181 (2003), 458-64, doi:10.1016/ j.surfcoat.2003.10.090

${ }^{48}$ P. Novak, D. Vojtch, J. Serak, V. Knotek, B. Bartova, Duplex surface treatment of the Nb-alloyed PM tool steel. Surf Coat Technol, 201 (2006), 3342-3349, doi:10.1016/j.surfcoat.2006.07.101

${ }^{49}$ P. L. Ge, M. D. Bao, H. J. Zhang, K. You, X. P. Liu, Effect of plasma nitriding on adhesion strength of CrTiAlN coatings on H13 steels by closed field unbalanced magnetron sputter ion plating. Surface \& Coatings Technology, 229 (2013), 146-150, doi:10.1016/j.surfcoat. 2012.08.002

${ }^{50}$ C. E. Shannon, W. Weaver The Mathematical Theory of Communication: University of Illinois Press., Urbana, III; 1949

${ }^{51}$ H. J. Gold, B. S. No, Application of Maximum Entropy and Minimum Cross-entropy Formalisms to Stochastic Modeling of Complex Dynamic Systems: Formulation of the Problem, Citeseer ;1983

${ }^{52}$ P. Nijkamp, Reflections on gravity and entropy models, Regional Science and Urban Economics, 5 (1975) 2, 203-225, doi:10.1016/ 0166-0462(75)90004-6

${ }^{53}$ A. Van Delft, P. Nijkamp, Multi-criteria analysis and regional decision-making. Springer Science \& Business Media 8 (1975), doi:10.3828/tpr.49.4.352126u261581260

${ }^{54}$ M. Zeleny, Linear multiobjective programming. Berlin: SpringerVerlag; 1974, doi:10.1007/978-3-642-80808-1

${ }^{55}$ M. Islamoglu, M. Apan, A. Oztel, An Evaluation of the Financial Performance of REITs in Borsa Istanbul: A Case Study Using the Entropy-Based TOPSIS Method. International Journal of Financial Research 6 (2015) 2, 124, doi:10.5430/ijfr.v6n2p124

${ }^{56}$ T.-C. Wang, J.-C. Hsu, Evaluation of the business operation performance of the listing companies by applying TOPSIS method. Paper presented at the Systems, Man and Cybernetics. 2004 IEEE International Conference, doi:10.1109/icsmc.2004.1399802

${ }^{57}$ D. L. Olson Decision aids for selection problems. Springer Science \& Business Media 1995, doi:10.1007/978-1-4612-3982-6

${ }^{58}$ I. Erol, S. Sencer, R. Sari, A new fuzzy multi-criteria framework for measuring sustainability performance of a supply chain. Ecological Economics, 70 (2011) 6, 1088-1100, doi:10.1016/j.ecolecon. 2011.01.001

${ }^{59}$ J. Zietsman, L. R. Rilett, S.-J. Kim, Transportation corridor decision-making with multi-attribute utility theory. International Journal of Management and decision making, 7 (2006) 2, 254-266, doi:10.1504/ijmdm.2006.009147

${ }^{60} \mathrm{M}$. Zeleny, Compromise programming. Multiple criteria decision making, MANJKA !!! 1973, 286

${ }^{61}$ P. L. Yu, Multiple-criteria decision making, Springer 1985, doi:10.1007/978-1-4684-8395-6

${ }^{62}$ I. Erol, S. Sencer, A. Özmen, C. Searcy, Fuzzy MCDM framework for locating a nuclear power plant in Turkey.Energy Policy 67 (2014), 186-197, doi:10.1016/j.enpol.2013.11.056

${ }^{63}$ F. J. André, C. Romero, Computing compromise solutions: on the connections between compromise programming and composite programming. Applied Mathematics and Computation 195 (2008) 1, 1-10,doi:10.1016/j.amc.2007.04.064

${ }^{64}$ E. Ballestero, C. Romero, Portfolio selection: A compromise programming solution. Journal of the Operational Research Society 1996: 1377-1386, doi:10.1057/jors.1996.173

${ }^{65}$ Öztel A, M. S. Köse, İ.Aytekin, Kurumsal Sürdürülebilirlik Performansının Ölçümü İçin Çok Kriterli Bir Çerçeve: Henkel Örneği. Tarih Kültür ve Sanat Araştırmaları Dergisi 1 (2012) 4, 32-44, doi:10.7596/taksad.v1i4.85 